\title{
ChemComm
}

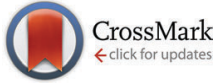

Cite this: Chem. Commun., 2015, 51, 5005

Received 4th December 2014 Accepted 13th February 2015

DOI: $10.1039 / c 4 c c 09671 a$

www.rsc.org/chemcomm

\section{Using nickel manganese oxide catalysts for efficient water oxidation $\dagger$}

\author{
Prashanth W. Menezes, ${ }^{a}$ Arindam Indra, ${ }^{a}$ Ophir Levy, ${ }^{a}$ Kamalakannan Kailasam, ${ }^{a}$ \\ Vitaly Gutkin, ${ }^{b}$ Johannes Pfrommer ${ }^{a}$ and Matthias Driess ${ }^{* a}$
}

\begin{abstract}
Nickel-manganese oxides with variable $\mathrm{Ni}: \mathrm{Mn}$ ratios, synthesised from heterobimetallic single-source precursors, turned out to be efficient water oxidation catalysts. They were subjected to oxidantdriven, photo- and electro-catalytic water oxidation showing superior activity and remarkable stability. In addition, a structureactivity relation could be established.
\end{abstract}

Splitting of water by an efficient catalyst is one of the major aspects of renewable energy research at present. ${ }^{1}$ Discovery of such highly active catalysts with scalable, abundant, robust, stable and low-cost materials is a promising solution for the sustainable production of clean energy. ${ }^{2}$ Over the years, firstrow transition metal oxides, particularly those with manganese oxide based systems have been widely investigated for photoand electrochemical reactions, ${ }^{3,4}$ not only due to their economic and environmental benefits but also because of the fact that nature enables solar to chemical energy conversion with a $\mathrm{Mn}_{4} \mathrm{CaO}_{5}$ cluster of photosystem II (PS II). ${ }^{5}$

In this context, several manganese oxides have been extensively explored for oxidant-driven, photo-catalytic and electro-catalytic water oxidation especially with nanocrystalline and amorphous manganese and calcium manganese oxides. ${ }^{6-11}$ Recently, we investigated different routes for the synthesis of various manganese oxides for efficient water oxidation. ${ }^{12,13}$ On the other hand, nickel based materials have drawn particular attention due to their earth abundant nature as well as their lower water oxidation potentials for efficient water oxidation catalysis. ${ }^{14-18}$ Although, we were successful in substitution of cobalt in manganese

\footnotetext{
${ }^{a}$ Metalorganic Chemistry and Inorganic Materials, Department of Chemistry, Technische Universität Berlin, Strasse des 17 Juni 135, Sekr. C2, D-10623 Berlin, Germany. E-mail: matthias.driess@tu-berlin.de

${ }^{b}$ The Harvey M. Krueger Family Center for Nanoscience and Nanotechnology, The Hebrew University of Jerusalem, Edmond J. Safra Campus, Givat Ram, Jerusalem, 91904, Israel

$\dagger$ Electronic supplementary information (ESI) available: Complete experimental details and characterisation of precursors and oxides before and after oxidantdriven, photo-catalytic and electro-catalytic water oxidation. See DOI: 10.1039/ c4cc09671a
}

oxides for enhanced redox oxygen catalysis, ${ }^{19}$ the role of nickel in manganese oxide has been merely examined. This is indeed because of the difficulties involved in the synthesis and the precise control over the composition with a maximum of dispersion of the nickel and manganese on the atomic level, and of the oxidation states of the metals. A while ago, Fukuzumi et al. reported a $\mathrm{NiMnO}_{3}$ phase toward water oxidation ${ }^{20}$ but other $\mathrm{Ni}$ : Mn ratios (compositions) of nickel manganese oxides have not been studied as yet. Therefore, we opted for the single-source precursor (SSP) approach to gain access to a new class of heterobimetallic nickel manganese oxides versus nickel oxide as promising catalysts for efficient oxidant-driven, photo- and electro-catalytic water oxidation.

First of all, nickel manganese and nickel oxalate SSPs were prepared in micro-emulsions containing cetyltrimethylammonium bromide (CTAB) as a surfactant, 1-hexanol as co-surfactant and hexane as the lipophilic phase and mixed with aqueous solution containing $\mathrm{Ni}^{2+}, \mathrm{Mn}^{2+}$ and oxalate ions with tuneable ratios. ${ }^{13}$ The thus yielded oxalate SSPs were treated thermally in the presence of dioxygen to form the respective oxide phases of various morphologies. (see ESI, $\dagger$ synthesis). The latter method is a reliable ways to access these low-cost materials in multigram-scale quantities.

All precursors were characterised extensively by state-of-the-art techniques and the corresponding data are given in Fig. S1-S9 and Tables S1 and S2 (ESI $\dagger$ ), respectively. The thermal degradation of the different heterobimetallic NiMn and homometallic $\mathrm{Ni}$ precursors in the presence of dioxygen produced the pure oxides phases $\mathrm{Ni}_{6} \mathrm{MnO}_{8}$ (JCPDS 42-479), $\mathrm{MnNi}_{2} \mathrm{O}_{4}$ (JCPDS 36-83), $\mathrm{NiMn}_{2} \mathrm{O}_{4}$ (JCPDS 1-1110) and NiO (JCPDS 71-1179), respectively, as confirmed by Powder X-Ray Diffraction (PXRD) analysis (Fig. S10, ESI $\dagger$ ). The chemical composition, quantification of $\mathrm{Ni}: \mathrm{Mn}$ ratio and their presence in the phase was obtained by Inductively Coupled Plasma (ICP) Atomic Emission Spectroscopy (AES) and Energy Dispersive X-ray (EDX) analysis (Fig. S11 and Table S3, ESI $\dagger$ ). Interestingly, just by tuning the nickel and manganese ratio, various morphologies have been realised. As shown in Fig. 1, the higher magnification Scanning Electron Microscopy (SEM) images of $\mathrm{Ni}_{6} \mathrm{MnO}_{8}$ showed a flower-type morphology $(\sim 1 \mu \mathrm{m})$ which consisted petals assembled from 


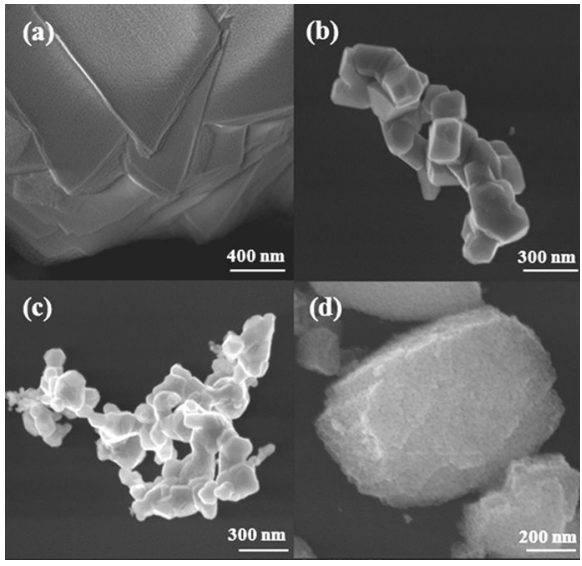

Fig. 1 SEM images of (a) $\mathrm{Ni}_{6} \mathrm{MnO}_{8}$, (b) $\mathrm{MnNi}_{2} \mathrm{O}_{4}$, (c) $\mathrm{NiMn}_{2} \mathrm{O}_{4}$ (d) $\mathrm{NiO}$

nanoparticles and $\mathrm{MnNi}_{2} \mathrm{O}_{4}$ displayed cubic type particles. $\mathrm{NiMn}_{2} \mathrm{O}_{4}$ forms small nanochains whereas $\mathrm{NiO}$ exhibits bricks $(\sim 400 \mathrm{~nm})$ built of tiny nanoparticles (see also Fig. S12, ESI $\dagger$ ). Further insights on the morphology and particles size were gathered by Transmission Electron Microscopy (TEM) and High Resolution (HR) TEM images (Fig. S13, ESI $\dagger$ ). In all cases the particles were well crystalline with particle size of about $2-5 \mathrm{~nm}$ for $\mathrm{Ni}_{6} \mathrm{MnO}_{8}, \sim 50 \mathrm{~nm}$ for $\mathrm{MnNi}_{2} \mathrm{O}_{4}, \sim 10 \mathrm{~nm}$ for $\mathrm{NiMn}_{2} \mathrm{O}_{4}$, and $\sim 5-10 \mathrm{~nm}$ for $\mathrm{NiO}$, respectively. The Fourier Transform Infrared (FTIR) spectrum of all oxides is typical and characteristic for metal oxalates (Fig. S14, ESI $\dagger$ ). The highest Brunauer-Emmett-Teller (BET) surface area was displayed for $\mathrm{Ni}_{6} \mathrm{MnO}_{8}\left(51.9 \mathrm{~m}^{2} \mathrm{~g}^{-1}\right)$ followed by $\mathrm{NiMn}_{2} \mathrm{O}_{4}$ $\left(39.6 \mathrm{~m}^{2} \mathrm{~g}^{-1}\right)$, NiO $\left(30.4 \mathrm{~m}^{2} \mathrm{~g}^{-1}\right)$, and $\mathrm{MnNi}_{2} \mathrm{O}_{4}\left(29.3 \mathrm{~m}^{2} \mathrm{~g}^{-1}\right)$, respectively (Fig. S15, ESI $\dagger$ ).

The detailed bonding states of $\mathrm{Ni}, \mathrm{Mn}$ and $\mathrm{O}$ were further characterised by X-ray Photoelectron Spectroscopy (XPS). The XPS core level spectra of $\mathrm{Ni}_{2} \mathrm{p}_{3 / 2}$ and $\mathrm{Ni} 2 \mathrm{p}_{1 / 2}$ for $\mathrm{Ni}_{6} \mathrm{MnO}_{8}, \mathrm{NiMn}_{2} \mathrm{O}_{4}$ and $\mathrm{NiO}$ exhibited peaks at binding energy (BE) of $\sim 854.5 \mathrm{eV}$ and $872.2 \mathrm{eV}$ corresponding to $\mathrm{Ni}^{2+}$ while the peaks of $\mathrm{MnNi}_{2} \mathrm{O}_{4}$ shifted to the higher energy of $856 \mathrm{eV}$ and $873.8 \mathrm{eV}$ which can be assigned as the mixture of $\mathrm{Ni}^{2+/ 3+}$ (Fig. S16, ESI $\dagger$ ). ${ }^{21}$ The Mn2p spectra of $\mathrm{Ni}_{6} \mathrm{MnO}_{8}$ and $\mathrm{MnNi}_{2} \mathrm{O}_{4}$ displayed two major peaks for $\mathrm{Mn} 2 \mathrm{p}_{3 / 2}$ and $\mathrm{Mn} 2 \mathrm{p}_{1 / 2}$ at $\mathrm{BE} \sim 643.5 \mathrm{eV}$ and $\sim 655.0 \mathrm{eV}$ that are consistent $\mathrm{Mn}^{4+}$ species whereas for $\mathrm{NiMn}_{2} \mathrm{O}_{4}$, the peak positions were shifted to lower energy of $642.4 \mathrm{eV}$ and $653.9 \mathrm{eV}$ and are characteristic for $\mathrm{Mn}^{3+}$ (Fig. S17, ESI $\dagger$ ). ${ }^{22}$ The O1s spectrum for all oxides exhibited a major $\mathrm{O}^{2-}$ peak assignable to bridging oxides with two smaller ones that could be attributed to the surface oxygen, physi- and chemisorbed water at or near the surface and to the hydroxide species (Fig. S18, ESI $\dagger$ ). ${ }^{19}$

Oxidant-driven water oxidation experiments (see $\mathrm{ESI} \dagger$ for details) were conducted with all catalysts (Fig. S19, ESI $\dagger$ ) in deoxygenated aqueous solution of $0.5 \mathrm{M}$ ceric ammonium nitrate (CAN) and the rate of the oxygen evolution was calculated from the slope of the linear fitting for the first $60 \mathrm{~s}$. The $\mathrm{Ni}_{6} \mathrm{MnO}_{8}$ was found to be extremely active with a maximum rate of $1.41 \mathrm{mmol}_{\mathrm{O} 2} \mathrm{~mol}_{\mathrm{M}}{ }^{-1} \mathrm{~s}^{-1}$ considering both nickel and manganese atoms are active, and was approximately thrice higher than the $\mathrm{MnNi}_{2} \mathrm{O}_{4}\left(0.52 \mathrm{mmol}_{\mathrm{O} 2} \mathrm{~mol}_{\mathrm{M}}{ }^{-1} \mathrm{~s}^{-1}\right)$. However, for $\mathrm{NiMn}_{2} \mathrm{O}_{4}$, the rate was far lesser with the value of
$0.19 \mathrm{mmol}_{\mathrm{O} 2} \mathrm{~mol}_{\mathrm{M}}{ }^{-1} \mathrm{~s}^{-1}$ and is comparable with the pure NiO $\left(0.15 \mathrm{mmol}_{\mathrm{O} 2} \mathrm{~mol}_{\mathrm{M}}{ }^{-1} \mathrm{~s}^{-1}\right)$. The surface area and the total number of active sites present on the catalyst play a crucial role in water oxidation. Therefore, the correlation of surface area normalised plots is shown in Fig. S20 (ESI $\dagger$ ) and follows the same trend as that of total mass activity.

The photo-catalytic water oxidation was performed in a phosphate buffer solution of $\mathrm{pH} 7$ in the presence of $\left[\mathrm{Ru}(\mathrm{bpy})_{3}\right]^{2+}(\mathrm{bpy}=2,2-$ bipyridine) as a photosensitiser and $\mathrm{S}_{2} \mathrm{O}_{8}{ }^{2-}$ as two electron acceptor (Scheme S1, ESI $\dagger$ ). In a similar trend to the oxidant-driven water oxidation, the highest rate of oxygen evolution was exhibited by the nickel-rich $\mathrm{Ni}_{6} \mathrm{MnO}_{8}$ with a value of $1.00 \mathrm{mmol}_{\mathrm{O} 2} \mathrm{~mol}_{\mathrm{M}}{ }^{-1} \mathrm{~s}^{-1}$ that was again 1.5 times higher than the other nickel-rich $\mathrm{MnNi}_{2} \mathrm{O}_{4}$ phase $\left(0.69 \mathrm{mmol}_{\mathrm{O} 2} \mathrm{~mol}_{\mathrm{M}}{ }^{-1} \mathrm{~s}^{-1}\right)$ (Fig. 2). The rate of oxygen evolution for the nickel-diluted $\mathrm{NiMn}_{2} \mathrm{O}_{4}$ was $0.44 \mathrm{mmol}_{\mathrm{O} 2} \mathrm{~mol}_{\mathrm{M}}{ }^{-1} \mathrm{~s}^{-1}$ while NiO showed only a limited activity $\left(0.07 \mathrm{mmol}_{\mathrm{O} 2} \mathrm{~mol}_{\mathrm{M}}{ }^{-1} \mathrm{~s}^{-1}\right)$. To compare the photo-catalytic activity, the commercial manganese oxides and nickel oxide were measured as standards that again showed that as-synthesised catalysts are highly active and of interest (Fig. S21, $\mathrm{ESI} \dagger$ ). Surface normalisation discloses that the values for $\mathrm{MnNi}_{2} \mathrm{O}_{4}$ are superior to $\mathrm{Ni}_{6} \mathrm{MnO}_{8}>\mathrm{NiMn}_{2} \mathrm{O}_{4} \gg \mathrm{NiO}$ due to their lower surface area (Fig. S22, ESI $\dagger$ ). Comparison of the mass and surface normalised activity with other reported catalysts confirmed that the diluted-manganese oxide based Ni systems produced higher oxygen evolution than most of the known active nickel and manganese based catalysts (Table S4, ESI $\dagger)^{7-10,20}$

After the Clark electrode experiments, a set of experiments for longer duration was also carried out separately (see ESI $\dagger$ ) and the oxygen gas was collected in the head space of the reaction mixture was quantitatively analysed by a gas chromatograph (GC). A maximum oxygen yield of $0.08 \mathrm{~mL} \mathrm{~h}{ }^{-1}$ of $\mathrm{O}_{2}$ was detected for $\mathrm{Ni}_{6} \mathrm{MnO}_{8}$ and $0.07 \mathrm{~mL} \mathrm{~h}^{-1}$ for $\mathrm{MnNi}_{2} \mathrm{O}_{4}$ (Table S5, ESI $\dagger$ ). Moreover, it is not enough to have catalysts that are extremely active but one of the indispensible criteria is also to know the fate of the catalyst after the photo-catalytic experiments, and therefore, PXRD and HRTEM investigation were conducted on high performance $\mathrm{Ni}_{6} \mathrm{MnO}_{8}$ and $\mathrm{MnNi}_{2} \mathrm{O}_{4}$ catalysts. From PXRD and HRTEM images (Fig. S23, ESI $\dagger$ ),

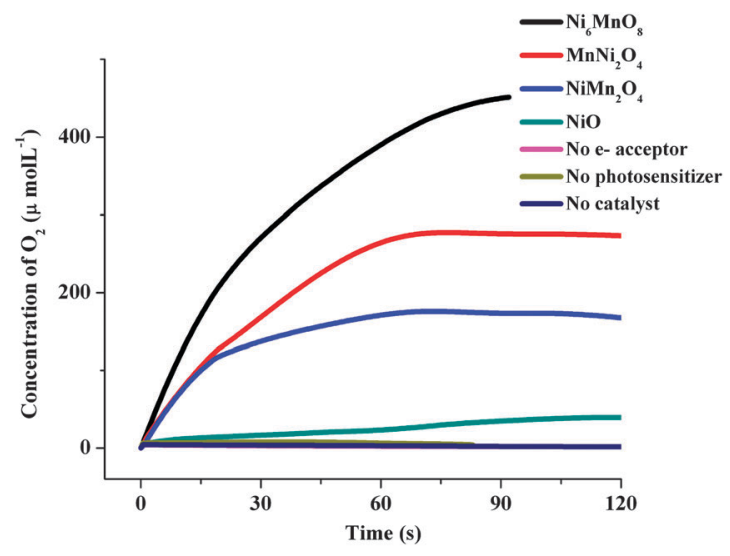

Fig. 2 Dissolved oxygen concentration profiles measured by Clark electrode containing $\mathrm{NiMn}-$ and $\mathrm{Ni}-$ oxide catalysts in $\mathrm{S}_{2} \mathrm{O}_{8}{ }^{2-}-\mathrm{Ru}(\mathrm{bpy})_{3}{ }^{2+}$ system using phosphate (pH 7) buffer (300 W Xe lamp with $395 \mathrm{~nm}$ cut-off filter). 


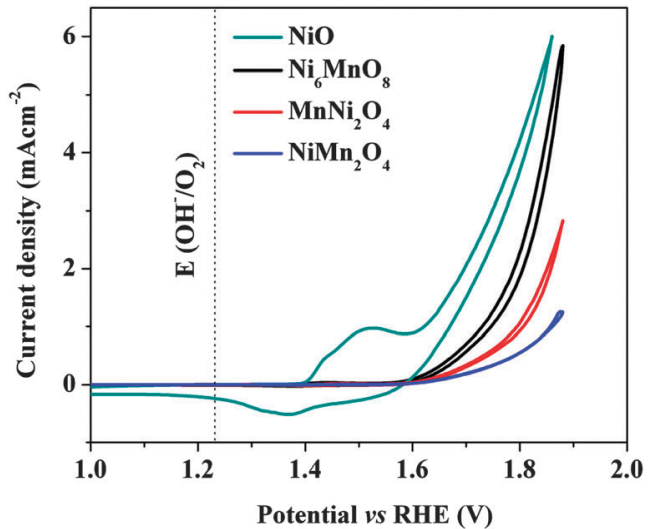

Fig. 3 Cyclic voltammograms (sweep rate $20 \mathrm{mV} \mathrm{s}^{-1}$ ) of nickel manganese and nickel oxide thin film catalysts in $0.1 \mathrm{M} \mathrm{KOH}(\mathrm{pH} 13)$.

it is clear that the crystallinity and the morphology of the nickel-rich manganese oxides catalysts were preserved and stayed intact unveiling the enhanced stability.

The electro-catalytic measurements (see ESI $\dagger$ ) were performed in alkaline $0.1 \mathrm{M} \mathrm{KOH}$ solution using Cyclic Voltammetry $(\mathrm{CV})$ at a scan rate of $20 \mathrm{mV} \mathrm{s}^{-1}$. The current for all electrodes were initially increased during the first few cycles and reached a steady value after 50 cycles (Fig. S24, ESI $\dagger$ ), and then stayed stable and were unchanged even after additional cycling. As shown in Fig. 3, For $\mathrm{Ni}_{6} \mathrm{MnO}_{8}$, the anodic current started growing at 1.54 (vs. the reversible hydrogen electrode, RHE). The maximum current density of $5.85 \mathrm{~mA} \mathrm{~cm}{ }^{-2}$ was attained at $1.87 \mathrm{~V}$. Similarly, for the $\mathrm{MnNi}_{2} \mathrm{O}_{4}$ and $\mathrm{NiMn}_{2} \mathrm{O}_{4}$, the current started increasing at 1.58 and $1.60 \mathrm{~V}$, and the highest current density was achieved at $2.83 \mathrm{~mA} \mathrm{~cm}^{-2}$ and $1.25 \mathrm{~mA} \mathrm{~cm}^{-2}$ at $1.87 \mathrm{~V}$, respectively. Interestingly, for $\mathrm{NiO}$, the current started growing at $1.40 \mathrm{~V}$ itself and the CV's featured a pair of anodic and cathodic peaks centred $\sim 1.5 \mathrm{~V} v s$. RHE corresponding to the oxidation of $\mathrm{NiO}\left(\mathrm{NiO}+\mathrm{OH}^{-}-1 \mathrm{e}^{-} \rightarrow \mathrm{NiOOH}\right)$, followed by a current due to $\mathrm{O}_{2}$ evolution. $^{23}$ Electrodes were also preconditioned and forward and backward scans were performed, with respect to the $\mathrm{NiO} / \mathrm{NiOOH}$ redox reaction of $\mathrm{NiO}$ (Fig. S25, ESI $\dagger$ ). ${ }^{16,24}$ It could also be seen that for the $\mathrm{Ni}_{6} \mathrm{MnO}_{8}, \mathrm{MnNi}_{2} \mathrm{O}_{4}$ and $\mathrm{NiMn}_{2} \mathrm{O}_{4}$, a small redox peak exists, suggesting the partial oxidation of $\mathrm{NiO}$ to $\mathrm{NiOOH}$ in the nickel manganese catalysts. The estimated overpotential for water oxidation at $1 \mathrm{~mA} \mathrm{~cm}^{-2}$ for $\mathrm{NiO}$ was $395 \mathrm{mV}$ while $\mathrm{Ni}_{6} \mathrm{MnO}_{8}, \mathrm{MnNi}_{2} \mathrm{O}_{4} \mathrm{NiMn}_{2} \mathrm{O}_{4}$ displayed an overpotential of 480, 560 and $610 \mathrm{mV}$, respectively (Table S6, $\mathrm{ESI} \dagger)$. The overpotential obtained for NiO here is slightly higher than the highly active ultra-small NiO nanoparticles but lesser than other known $\mathrm{NiO}$ as well as $\mathrm{Ni}(\mathrm{OH})_{2}$ nanoplates and nanoparticles (see also Table S7, ESI $\dagger$ ). ${ }^{16-18,23,25,26}$ Also similar trend was extended when normalised with the surface area suggesting that more active sites are available on the surface of $\mathrm{NiO}$ than the nickel manganese oxides (Fig. S26). Tafel slopes were extracted in the potential range of 1.55 to $1.80 \mathrm{~V}$ and a Tafel slope of $65 \mathrm{mV}$ per decade was achieved for NiO whereas $88 \mathrm{mV}$ per decade for $\mathrm{Ni}_{6} \mathrm{MnO}_{8}$ associated with a rate determining chemical step preceded by a reversible electrochemical step at equilibrium (Fig. S27, ESI $\dagger$ ). Increase in the apparent Tafel slope values were seen for $\mathrm{MnNi}_{2} \mathrm{O}_{4}$ and $\mathrm{NiMn}_{2} \mathrm{O}_{4}$ that could correspond to a change in the reaction mechanism but would also be expected if mass or ion transport limitations became significant. ${ }^{27,28} \mathrm{How}^{-}$ ever, from the above electrochemical behaviour, it can be inferred that a higher content of Ni ions in the structure leads to lower Tafel slopes and thus, beneficial electro-catalytical properties.

Furthermore, to test the stability of all catalysts, chronoamperometric experiments were carried out (Fig. S28, ESI $\dagger$ ) and the current values for $\mathrm{NiO}$ and $\mathrm{NiMn}_{2} \mathrm{O}_{4}$ were maintained over the period of 15 hours. In the case of $\mathrm{Ni}_{6} \mathrm{MnO}_{8}$, increased current values were achieved demonstrating the exceptional stability of catalysts on a long run. On the other hand, a slight decrease in currents was observed for $\mathrm{MnNi}_{2} \mathrm{O}_{4}$.

After the long-term stability tests, the electrodes were further characterised by TEM and CV. HRTEM images of $\mathrm{NiO}, \mathrm{Ni}_{6} \mathrm{MnO}_{8}$ and $\mathrm{MnNi}_{2} \mathrm{O}_{4}$ revealed that an amorphous shell of $\mathrm{NiOOH}$ appears on the surface of the catalysts, which has already been well described for the $\mathrm{Ni}$ based catalysts (Fig. S29, ESI $\dagger$ ). ${ }^{16,23}$ After chronoamperometry, the NiO electrode was subjected to CV attaining a lower overpotential $\left(370 \mathrm{mV}\right.$ at $\left.1 \mathrm{~mA} \mathrm{~cm}{ }^{-1}\right)$ with slightly lower current density, which unveils the impressive nature of the catalyst with prolonged durability (Fig. S30, ESI $\dagger$ ). In addition to the alkaline media, the NiO catalyst was also studied in neutral ( $\mathrm{pH} 7$ ) and slightly basic ( $\mathrm{pH} 9)$ conditions using phosphate and borate buffers and in $\mathrm{KOH}$ solution of $\mathrm{pH} 11$, but only resulting into lower activity (Fig. S31, ESI $\dagger$ ). The determined Tafel slope at $\mathrm{pH} 11$ was lower than $\mathrm{pH} 13$ elucidating slower kinetics at lower $\mathrm{pH}$ (Fig. S32, ESI $\dagger$ ).

Based on the higher activity of nickel-rich manganese oxides for oxidant-driven and photo-catalytic water oxidation $\left(\mathrm{Ni}_{6} \mathrm{MnO}_{8}>\mathrm{MnNi}_{2} \mathrm{O}_{4}>\mathrm{NiMn}_{2} \mathrm{O}_{4}>\mathrm{NiO}\right)$, and conversely, nickel oxide $\left(\mathrm{NiO}>\mathrm{Ni}_{6} \mathrm{MnO}_{8}>\mathrm{MnNi}_{2} \mathrm{O}_{4}>\mathrm{NiMn}_{2} \mathrm{O}_{4}\right.$ ) for electrochemical OER, a structure activity relation can be deduced. The crystal structure of $\mathrm{Ni}_{6} \mathrm{MnO}_{8}$ is cubic (space group $\mathrm{Fm} 3 \mathrm{~m}$ ) and may be considered as rock-salt structure where $6 / 8$ of octahedral sites are occupied by $\mathrm{Ni}^{2+}$ atoms and $1 / 8$ by $\mathrm{Mn}^{4+}$ atoms, and by vacancies. ${ }^{29}$ The vacancies are ordered in the alternative (111) planes (Fig. 4a). Under oxidant-driven and photochemical conditions, not only the $\mathrm{Ni}_{6} \mathrm{MnO}_{8}$ provides more active sites due to the presence of higher number of $\mathrm{Ni}^{2+}$ as active centres that are supported and stabilised by $\mathrm{Mn}^{4+}$ but also an additional (extra) hole density drives this reaction efficiently. However, both $\mathrm{MnNi}_{2} \mathrm{O}_{4}$ and $\mathrm{NiMn}_{2} \mathrm{O}_{4}$ crystallise in cubic (space group $F d 3 m$ ) system and belong to the spinel type $\left(\mathrm{AB}_{2} \mathrm{O}_{4}\right)$ structure (Fig. 4b). ${ }^{30,31}$ The $\mathrm{Mn}^{4+}$ ions occupy the tetrahedral sites and the octahedral sites are preferred by $\mathrm{Ni}^{2+/ 3+}$ for $\mathrm{MnNi}_{2} \mathrm{O}_{4}$ whereas the tetrahedral sites are occupied by $\mathrm{Ni}^{2+}$ and octahedral by $\mathrm{Mn}^{3+}$ for $\mathrm{NiMn}_{2} \mathrm{O}_{4}$. It has been already well described that the octahedral sites in a spinel structure play a prominent role than that of tetrahedral sites for water oxidation making $\mathrm{Ni}^{2+/ 3+}$ higher active than $\mathrm{Mn}^{3+}$ and that itself explains the higher activity of $\mathrm{MnNi}_{2} \mathrm{O}_{4}$ in comparison to the $\mathrm{NiMn}_{2} \mathrm{O}_{4} \cdot{ }^{32-34}$ The NiO (cubic Fm3m) adopts a rock-salt structure ${ }^{35}$ similar to $\mathrm{Ni}_{6} \mathrm{MnO}_{8}$ (Fig. 4c) with octahedral $\mathrm{Ni}^{2+}$ and $\mathrm{O}^{2-}$ and perhaps because of unavailable support of manganese, displays limited activity. 


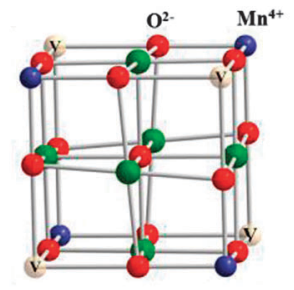

(a)

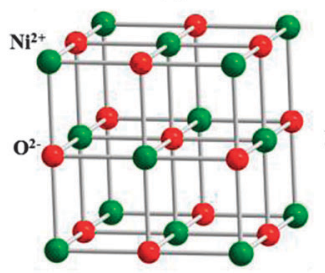

(c)

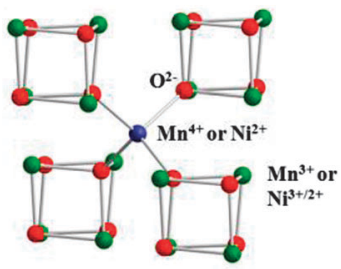

(b)

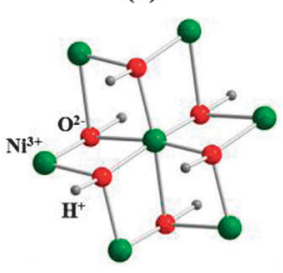

(d)
Fig. 4 Structural units of (a) $\mathrm{Ni}_{6} \mathrm{MnO}_{8}$, (b) $\mathrm{MnNi}_{2} \mathrm{O}_{4}$ or $\mathrm{NiMn}_{2} \mathrm{O}_{4}$, (c) $\mathrm{NiO}$ and (d) $\mathrm{NiOOH}$ (see text for details). Atom codes, blue: $\mathrm{Mn}^{4+}$ or $\mathrm{Ni}^{2+}$; green: $\mathrm{Ni}^{2+}, \mathrm{Ni}^{3+/ 2+}$ or $\mathrm{Mn}^{3+}$; red: $\mathrm{O}^{2-}$; gray: $\mathrm{H}^{+}$, yellow: vacancy.

The situation is partly reversed in the electrochemical water oxidation. The NiO exhibits highest activity followed by nickel manganese oxides. This is due to a large amount of amorphous $\mathrm{NiOOH}$, where $\mathrm{Ni}^{3+}$ is hexa- coordinated (Fig. $4 \mathrm{~d}$ ), ${ }^{36}$ is formed on the surface of the electrodes (as shown by TEM and XPS) under electrochemical conditions and the resulting amorphous phase is known to be active for water oxidation by making the system very efficient and has been already well established for other nickel oxide and hydroxides. ${ }^{16,23,25}$ Interestingly, for $\mathrm{Ni}_{6} \mathrm{MnO}_{8}, \mathrm{MnNi}_{2} \mathrm{O}_{4}$, and $\mathrm{NiMn}_{2} \mathrm{O}_{4}$ lesser amount of $\mathrm{NiOOH}$ is generated depending on the amount of nickel present in the catalysts. Therefore, it can be concluded that for oxidant-driven and photo-catalytic water oxidation $\mathrm{Ni}_{6} \mathrm{MnO}_{8}$ is efficient due to the higher amount of $\mathrm{Ni}$ active sites stabilised by manganese and higher structural-hole density whereas amorphous $\mathrm{NiOOH}$ seems to be crucial for electro-catalytic water oxidation due to its structural features.

In conclusion, we investigated for the first time, the oxidantdriven, photochemical and electrochemical water oxidation employing nickel manganese oxide-based catalysts $\left(\mathrm{Ni}_{6} \mathrm{MnO}_{8}\right.$, $\mathrm{MnNi}_{2} \mathrm{O}_{4}, \mathrm{NiMn}_{2} \mathrm{O}_{4}$ ) with various $\mathrm{Ni}$ : $\mathrm{Mn}$ ratios and morphologies, starting from well-defined heterobimetallic nickel manganese SSPs; their activities were compared with NiO. Nickel-rich manganese oxides were found to be highly efficient with very high activity for oxidant-driven and photo-catalytic water oxidation whereas $\mathrm{NiO}$ exhibited higher performance and remarkable stability for electrocatalytic water oxidation. Based on the crystallographic aspects, a structure-activity relationship could be deduced from structural features of the oxide systems. The latter relationship deduced here can help to predesign new material to boost efficiency of water oxidation.

Financial support by the BMBF (L2H project) and the DFG (Cluster of Excellence UniCat) is gratefully acknowledged. O. Levy would like to thank Einstein Foundation Berlin for the financial support and Prof. David Avnir for the helpful discussions.

\section{Notes and references}

1 J. Luo, J.-H. Im, M. T. Mayer, M. Schreier, M. K. Nazeeruddin, N.-G. Park, S. D. Tilley, H. J. Fan and M. Gratzel, Science, 2014, 345, 1593-1596.

2 M. W. Kanan and D. G. Nocera, Science, 2008, 321, 1072-1075.

3 A. Singh and L. Spiccia, Coord. Chem. Rev., 2013, 257, 2607-2622.

4 A. Indra, P. W. Menezes, N. R. Sahraie, A. Bergmann, C. Das, M. Tallarida, D. Schmeißer, P. Strasser and M. Driess, J. Am. Chem. Soc., 2014, 136, 17530-17536.

5 H. Dau, C. Limberg, T. Reier, M. Risch, S. Roggan and P. Strasser, ChemCatChem, 2010, 2, 724-761.

6 A. Iyer, J. Del-Pilar, C. K. King'ondu, E. Kissel, H. F. Garces, H. Huang, A. M. El-Sawy, P. K. Dutta and S. L. Suib, J. Phys. Chem. C, 2012, 116, 6474-6483.

7 M. M. Najafpour, T. Ehrenberg, M. Wiechen and P. Kurz, Angew. Chem., Int. Ed., 2010, 49, 2233-2237.

8 M. M. Najafpour, F. Rahimi, M. Amini, S. Nayeri and M. Bagherzadeh, Dalton Trans., 2012, 41, 11026-11031.

9 F. Jiao and H. Frei, Chem. Commun., 2012, 46, 2920-2922.

10 F. Jiao and H. Frei, Energy Environ. Sci., 2012, 3, 1018-1027.

11 Y. Meng, W. Song, H. Huang, Z. Ren, S.-Y. Chen and S. L. Suib, J. Am. Chem. Soc., 2014, 136, 11452-11464.

12 A. Indra, P. W. Menezes, I. Zaharieva, E. Baktash, J. Pfrommer, M. Schwarze, H. Dau and M. Driess, Angew. Chem., Int. Ed., 2013, 52, 13206-13210.

13 P. W. Menezes, A. Indra, P. Littlewood, M. Schwarze, C. Göbel, R. Schomäcker and M. Driess, ChemSusChem, 2014, 7, 2202-2211.

14 R. D. L. Smith, M. S. Prevot, R. D. Fagan, Z. Zhang, P. A. Sedach, M. K. J. Siu, S. Trudel and C. P. Berlinguette, Science, 2013, 340, 60-63.

15 Y. Yang, H. Fei, G. Ruan, C. Xiang and J. M. Tour, ACS Nano, 2014, 8, 9518-9523.

16 K. Fominykh, J. M. Feckl, J. Sicklinger, M. Döblinger, S. Boecklein, J. Ziegler, L. Peter, J. Rathousky, E.-W. Scheidt, T. Bein and D. Fattakhova-Rohlfing, Adv. Funct. Mater., 2014, 24, 3123-3129.

17 J. Suntivich, K. J. May, H. A. Gasteiger, J. B. Goodenough and Y. Shao-Horn, Science, 2012, 334, 1383-1385.

18 E. L. Miller and R. E. Rocheleau, J. Electrochem. Soc., 1997, 144, 1995-2003.

19 P. W. Menezes, A. Indra, R. N. Saharie, A. Bergmann, P. Strasser and M. Driess, ChemSusChem, 2015, 8, 164-171.

20 D. Hong, Y. Yamada, A. Nomura and S. Fukuzumi, Phys. Chem. Chem. Phys., 2013, 15, 19125-19128.

21 M. Elbaydi, S. K. Tiwari, R. N. Singh, J. L. Rehspringer, P. Chartier, J. F. Koenig and G. Poillerat, J. Solid State Chem., 1995, 116, 157-169.

22 H. W. Nesbitt and D. Banerjee, Am. Mineral., 1998, 83, 305-315.

23 M. Gao, W. Sheng, Z. Zhuang, Q. Fang, S. Gu, J. Jiang and Y. Yan, J. Am. Chem. Soc., 2014, 136, 7077-7084.

24 M. E. G. Lyons and M. P. Brandon, Int. J. Electrochem. Sci., 2008, 3, 1386-1424.

25 L. Trotochaud, J. K. Ranney, K. N. Williams and S. W. Boettcher, J. Am. Chem. Soc., 2012, 134, 17253-17261.

26 C. C. L. McCrory, S. Jung, J. C. Peters and T. F. Jaramillo, J. Am. Chem. Soc., 2013, 135, 16977-16987.

27 Y. Surendranath, M. W. Kanan and D. G. Nocera, J. Am. Chem. Soc., 2010, 132, 16501-16509.

28 S. W. Lee, C. Carlton, M. Risch, Y. Surendranath, S. Chen, S. Furutsuki, A. Yamada, D. G. Nocera and Y. Shao-Horn, J. Am. Chem. Soc., 2012, 134, 16959-16962.

29 P. Porta, G. Minelli, I. L. Botto and E. J. Baran, J. Solid State Chem., 1991, 92, 202-207.

30 A. B. Devale and D. K. Kulkarni, J. Phys. C, 1982, 15, 899-905.

31 S. Asbrink, A. Waskowska, M. Drozd and E. Talik, J. Phys. Chem. Solids, 1997, 58, 725-729.

32 T. W. Kim, M. A. Woo, M. Regis and K.-S. Choi, J. Phys. Chem. Lett., 2014, 5, 2370-2374.

33 E. Rios, P. Chartier and J. L. Gautier, Solid State Sci., 1999, 1, 267-277.

34 Y. Liang, H. Wang, J. Zhou, Y. Li, J. Wang, T. Regier and H. Dai, J. Am. Chem. Soc., 2011, 134, 3517-3523.

35 S. Sasaki, K. Fujino and Y. Takeuchi, Proc. Jpn. Acad., Ser. B, 1979, 55, 43-48.

36 M. Casas-Cabanas, J. Canales-Vazquez, J. Rodriguez-Carvajal and M. R. Palacin, Solid State Ionics, 2009, 131-136. 